\title{
OPTIMASI PENATAAN ACCESS POINT PADA JARINGAN NIRKABEL MENGGUNAKAN ALGORITMA SIMULATED ANNEALING
}

\author{
I. G. S. Artawan'), G. S. Santyadiputra ${ }^{2)}$, K. Agustini ${ }^{3)}$ \\ Fakultas Teknik dan Kejuruan, Universitas Pendidikan Ganesha (I Gede Suka Artawan) \\ Fakultas Teknik dan Kejuruan, Universitas Pendidikan Ganesha (Gede Saindra Santyadiputra) \\ Fakultas Teknik dan Kejuruan, Universitas Pendidikan Ganesha (Ketut Agustini) \\ 1,2,3Pendidikan Teknik Informatika, Universitas Pendidikan Ganesha \\ 1,2,3 Jalan Udayana No. 11 Singaraja - Bali 81116 \\ 19awangede92@gmail.com, ${ }^{2}$ gsaindras@undiksha.ac.id, ${ }^{3 k}$ ketutagustini@undiksha.ac.id
}

\begin{abstract}
ABSTRAK
Optimasi penataan access point adalah salah satu permasalahan dalam bidang pengembangan infrastruktur jaringan. Dalam optimasi tersebut memerlukan suatu analisis sebelum diimplementasikan. Tujuan optimasi pada access point yaitu mendeskripsikan penerapan algoritma Simulated Annealing (SA) dalam optimasi penataan access point pada jaringan nirkabel di Auditorium Undiksha dan mengukur perbedaan sebelum dan sesudah dilakukan optimasi. Metode yang digunakan dalam penelitian ini adalah SADTC yang tediri dari 5 tahapan, yaitu Studies, Analysis, Design, Testing, dan Conclusion. Dalam tahapan design dari metode tersebut digunakan 2 kondisi yaitu pemodelan sistem berdasarkan kondisi sebenarnya dan pemodelan sistem berdasarkan algoritma Simulated Annealing. Hasil dari 2 kondisi dengan 3 access point yang berbeda diperoleh persentase coverage area awal sebesar $11 \%$ dan ketika diterapkannya algoritma Simulated Annealing hasilnya berupa 10 titik koordinat dari 3 access point yang berbeda serta nilai coverage area dengan rata-rata persentase sebesar $20 \%$ untuk access point $1,18 \%$ untuk access point2, dan $20 \%$ untuk access point3. Dari hasil penelitian tersebut diharapkan mampu menentukan pemodelan yang sesuai saat mengimplementasikan optimasi penataan access point pada jaringan Nirkabel menggunakan algoritma Simulated Annealing
\end{abstract}

Kata kunci: Optimasi, Access Point, INSSIDER, Coverage Area, Simulated Annealing.

\begin{abstract}
Optimization of the arrangement of access points is one of the problems in the development of network infrastructure. In such optimization requires analysis before it is implemented. The purpose of optimization of the access point that describes the application of the algorithm Simulated Annealing (SA) in the optimization of the arrangement of the access point on the wireless network at the Undiksha Auditorium and measures the difference before and after optimization. The method used in this study is SADTC consisting of five stages, namely Studies, Analysis, Design, Testing, and Conclusion. In the design stage of the method two conditions are used namely, the modeling system based on the actual conditions and the algorithm based modeling system on Simulated Annealing. The results of these 2 conditions with three access points that differ obtained the percentage coverage area beginning at $11 \%$ and when the implementation of the algorithm Simulated Annealing result is a 10-point coordinates of the three access points are different as well as the value of the coverage area with an average percentage of $20 \%$ for access points $1,18 \%$ to access points 2 , and $20 \%$ for access points3. The results of these studies are expected to determine the appropriate modeling while implementing an optimization arrangement for Wireless access points on the network using a Simulated Annealing algorithm.
\end{abstract}

Keywords: Optimization, Access Point, INSSIDER, Coverage Area, Annealing Simulation 


\section{PENDAHULUAN}

Belakangan ini pemanfaatan jaringan komputer di dalamnya ada konsep target. Konsep target merupakan sebuah sistem komputer yang dibantu oleh tiga komponen utama, yaitu Hardware, (Software), dan (Brainware), bahwa pihak dari pengguna bertanggung jawab atas semua pengembangan [1] salah satunya adalah Wi-Fi (Wireless Fidelity). Pemanfaatan Wi-fi juga memerlukan perencanaan yang terstruktur tidak sekedar memasang perangkat jaringan yang diperlukan. Wi-Fi merupakan teknologi menggunakan kabel sebagai media transmisinya dengan memanfaatkan radiasi elektromagnetik atau disebut juga gelombang radio [2]. Posisi access point merupakan salah satu faktor yang dapat memepengaruhi penerimaan sinyal dari access point (Transmiter) terhadap perankat penerima (Receiver). Semakin optimal penempatan access point, maka semakin optimal juga akses Wi-fi untuk penerima [3], [4]. Posisi access point sangat berpengaruh terhadap area tercover untuk penerima pada sebuah jaringan Wi-Fi [5]. Optimalisasi penempatan posisi AP merupakan salah satu permasalahan di bidang infrastruktur jaringan [6]. Peletakan sistem Wi-Fi yang baik diperlukan untuk mengoptimalkan level daya terima dari transmitter ke receiver.

Penataan access point yang dilakukan secara manual menyebabkan kurang optimalnya kekuatan sinyal di beberapa tempat di area kampus seperti pada Gedung Auditorium Undiksha serta adanya area blankspot. Maka dari itu optimasi optimasi penataan access point dilakukan dengan kondisi eksisting menggunakan algoritma Simulated Annealing. Optimasi kegiatan untuk memperoleh hasil terbaik yang bisa diterima sesuai dengan keadaan yang diberikan tergantung pada masalah yang diteliti. Allgoritma Simulated Annealing digunakan karena metode untuk menyelesaikan masalah optimasi yang tidak dibatasi. Pemodelan yang digunakan diharapkan bisa memenuhi dan dapat meningkatkan kekuatan sinyal yang diterima oleh user. Namun solusi yang bagus belum tentu hasilnya optimum tetapi sudah bisa diterima oleh pihak pengguna atau user.

Saat ini sudah ada beberapa penelitian yang membahas tentang optimasi penataan access point. Penelitian yang dilakukan oleh [7] membahas analisis dan pemodelan posisi access point pada jaringan Wi-fi (Wirelless Fidelity). Penghitungan terhadap parameter-parameter yang dicari yaitu menentukan fungsi objektif dari Simulated Annealing yang dihasilkan dari fungsi jarak, penghalang, ketinggian transmitter, pengguna, tipe dan merk access point. Selajutnya, penelitianyang dilakukan oleh [8] dalam penelitian ini hal pertama yang dilakukan adalah menentukan gambaran awal posisi access point. Selanjutnya dilakukan pengujian berdasarkan jarak antar access point dan posisi access point. Terakhir melakukan perhitungan berdasarkan parameter-parameter yang dicari untuk menentukan ngarea jangkauan maksimum yaitu fungsi jarak, pengaruh tinggi transmitter terhadap nilai RSSI (Received Signal Strength Indication).

Dilihat dari penelitian dan penataan sebelumnya, maka dilakukan sebuah penelitian optimasi penataan access point pada jaringan nirkabel menggunakan algoritma Simulated Annealing yang diharapkan mampu mensupport seluruh area dengan kualitas sinyal yang lebih kuat. Dari 5 tahapan metode yang digunakan yaitu Studies, Analysis, Design, Testing, dan Conclusion. Pada tahapan Design merupakan hasil akhir dari penelitian ini sehingga diperoleh 2 kondisi, yaitu pemodelan sistem berdasarkan kondisi sebenarnya dan pemodelan sistem berdasarkan algoritma Simulated Annealing.

\section{METODE}

Metode penelitian yang digunakan adalah SADTC (Studies, Analysis, Design, Testing, dan Conclusion). Terdapat 5 tahapan, seperti pada gambar 1 berikut: 


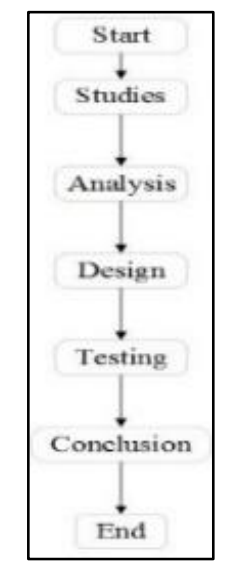

Gambar 1. Alur Metode SADTC

a. Studies / Studi Literatur

Konsep Algoritma Pencarian yaitu Algoritma Simulated Annealing digunakan di dalam penelitian ini [9].

b. Analysis / Analisis

Analisa yang dilakukan meliputi lokasi penelitian dilakukan di Gedung Auditorium Undiksha Singaraja-Bali. Analisis kondisi lingkungan yang dilakukan meliputi denah / blueprint dari Gedung Auditorium, penempatan access point, dan nilai daya pancar sinyal dari access point.

c. Design / Desain

Tahapan ini dilakukan optimasi yang nantinya akan mengarah ke algoritma optimasi Simulated Annealing dengan menggunakan 2 kondisi yaitu:

1. Pemodelan Sistem berdasarkan Kondisi sebenarnya.

Pada pemodelan ini dilakukan pengambilan data kondisi eksisting, seperti berikut:

- Pembagian luas area (denah) berdasarkan panjang dan lebar dan menentukan titik koordinat $(x, y)$.

- Menentukan jumlah access point, yang terdiri dari jumlah access point berdasarkan coverage area dan kapasitas user sesuai dengan parameter sistem pada access point seperti pada tabel 1 berikut:

Tabel 1. Parameter Sistem Access Point

\begin{tabular}{lll}
\hline Merk Access Point & $:$ Ubiquiti NanoStation Loco M2/LOCOM2 \\
\hline Frekuensi & $: 2,4 \mathrm{GHz} \mathrm{b} / \mathrm{g} / \mathrm{n}$ \\
Power Transmit & $: 23 \mathrm{dBm}$ \\
Gain Antenna & $: \quad 8 \mathrm{dBi}$ \\
Tinggi Antena & $: 4 \mathrm{~m}$ \\
Sensitivity Receiver & $:-70 \mathrm{dBm}$ \\
Max. Data Rate & $: 100 \mathrm{Mbps}$ \\
Baseline Rate & $: 5 \mathrm{Mbps}$
\end{tabular}

- Ketinggian access poin 4 meter.

- Menentukan titik koordinat Transmiter ke-1 dengan posisi access point sebenarnya.

- Mengukur besarnya nilai RSSI dari sesuai bertambahnya jarak antara koordinat kedua Transmiter dan koordinat Receiver.

- Menghitung jarak ( $\delta$ ), Range ( $\rho$ ) Menghitung Luas Area Tercover (LCA), Total area tercover (ろ), dan Coverage Area (\%)

2. Pemodelan Sistem berdasarkan Algoritma Simulated Annealing. Pada pemodelan ini terdapat 4 proses di dalamnya, sebagai berikut:

- Fungsi Objektif, bertujuan untuk menemukan nilai dari daerah yang tertutup terbesar berdasarkan nilai dari jarak antara transmitter dan posisi receiver di antara sejumlah titik akses yang telah diinisialisasi secara acak [10].

- Inisialisasi dan mekanisme pembetukan solusi baru, solusi awal untuk pembentukan penempatan titik akses diinisialisasi secara acak dengan cara membagi jalur akses secara acak ke dalam koordinat.

- Skema pendinginan, sebelum proses annealing dilakukan, skema pendingin harus ditetapkan terlebih dahulu. 
- Iterasi, proses iterasi dilakukan bertujuan untuk mencari nilai Coverage Area (\%) yang paling optimal untuk area yang tertutup.

d. Testing / Pengujian

Tahap pengujian pada penelitian ini membandingkan hasil perhitungan pada sistem dengan perhitungan manual yang dilakukan.

e. Conclusion / Kesimpulan

Penarikan suatu kesimpulan dari hasil uji coba yang sesuai dengan masalah yang diangkat dalam penelitian. Di dalam tahapan ini juga terdapat saran dari penelitian yang sudah dilakukan guna menunjang penelitian selanjutnya.

\section{HASIL DAN PEMBAHASAN}

Hasil dari penelitian ini diperoleh data analisis penempatan sebuah access point:

1. Pemodelan Sistem berdasarkan Kondisi Sebenarnya.

a. Pemodelan dimulai dari melakukan pembagian luas ruangan. Sample denah yang digunakan memiliki luas $2.021 \mathrm{~m}^{2}$ pada gambar 2 berikut:

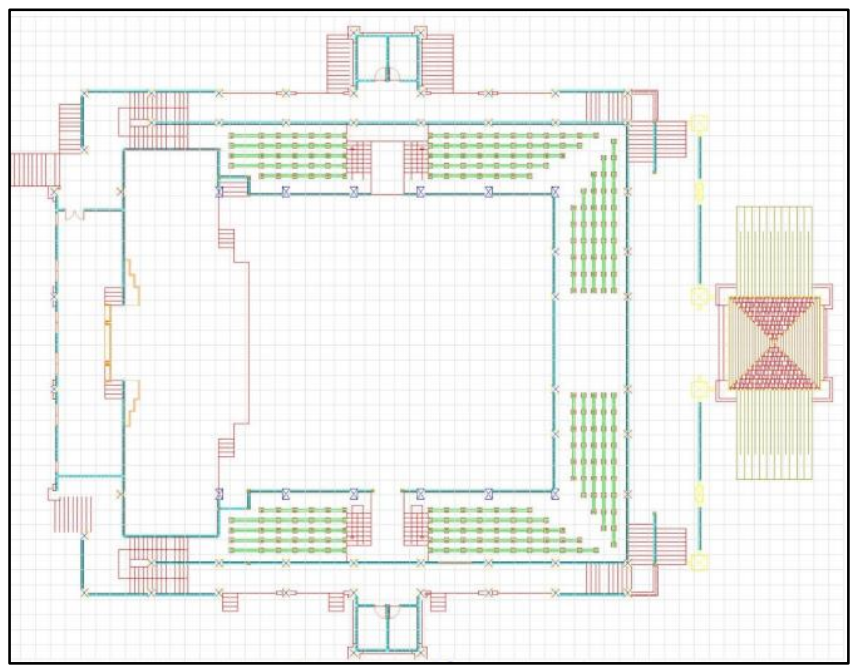

Gambar 2. Sample Lokasi Penelitian

b. Menentukan jumlah access point berdasarkan coverage area seperti berikut:

- Menentukan nilai maksimum pelemahan sinyal ini biasa disebut dengan Maximum Allowable Path Loss (MAPL dengan persamaan (1):

$$
\begin{gathered}
L p=L_{F S L}=32,45+20_{\text {log }} f(\text { Frekuensi } A P) \\
L p=20_{\log } d(\mathrm{Km}) \\
L_{F S L}=100
\end{gathered}
$$

- Untuk menghitung kekuatan daya pancar suatu antena atau sering disebut EIRP (Effective Isotropic Radiated Power) menggunakan persamaan (2) dan (3):

$$
\begin{gathered}
E I R P=P_{\text {Transmit }}-L_{r x}+G_{\text {antena }} \\
\text { IIRP }=23-0+8 \\
E I R P=31 \\
M A P L=E I R P-\text { Margin }-S_{r x} \\
M A P L=31-10-(-67) \\
M A P L=88 d B
\end{gathered}
$$

- Level Sinyal yang diterima disisi penerima RSL (Receiver Signal Leve). Keadaan baik, jika RSL $\leq$ Rth (Sentivitas Penerima) [11]. Dengan menggunakan persamaan (4).

$$
\begin{gathered}
R S L=E I R P-L_{F S L}+G_{\text {antena }}-L_{r x}(4) \\
R S L=31-100+8-0 \\
R S L=-61 d B
\end{gathered}
$$

- Hitung nilai SOM (System Operating Margin) dengan persamaan (5). SOM adalah perbedaan antara sinyal radio sebenarnya dengan kualitas sinyal yang diperlukan. SOM dihitung dengan persamaan (5). Nilai SOM harus 10-15 dB:

$$
S O M=R S L-S_{r x}
$$




$$
\begin{gathered}
S O M=-61-(-67) \\
S O M=7 \mathrm{~dB}
\end{gathered}
$$

- Selanjutnya menghitung coverage area dari access point menggunakan persamaan (6):

$$
\begin{gathered}
P L_{(d)}=P L_{F S}+26,9=>M A P L=P L_{(d)} \\
P L_{F S}=P L_{(d)}-26,9=61,1 \mathrm{~dB} \\
P L_{F S}=20 \log \frac{4 \pi r}{\lambda} \\
61,1=20 \log \frac{4 x 3,14 x r}{0,125} \\
r=11,29588=11 \mathrm{~m}
\end{gathered}
$$

- Jadi, luas coverage area WLAN dengan $r=11 \mathrm{~m}$. Luas coverage area $=2,6 \times \mathrm{r}^{2}=314,6$ $\mathrm{m}^{2}$. Maka luas cakupan area WLAN adalah sebesar $314,6 \mathrm{~m} 2$, dimana luas area gedung sebesar $2.021 \mathrm{~m}^{2}$. Diharapkan dapat meningkatkan produktifitas penggunaan wireless LAN juga merupakan alternatif terbaik solusi jaringan di era global [12]. Jadi untuk menentukan jumlah access point yang diperlukan adalah dengan persamaan (6):

$$
\frac{2.021}{314,6}=6,421=6 A P
$$

Keterangan:

$\begin{array}{ll}\text { LFSL } & : \text { Free Space Loss } \\ \mathrm{G}_{\text {antena }} & : \text { Gainanten } \\ \mathrm{L}_{\mathrm{rx}} & : \text { Rugi-rugi redaman } \\ \mathrm{S}_{\mathrm{rx}} & : \text { Sensitifitas AP } \\ \text { Margin } & : 10 \mathrm{~dB} \text { Typical untuk WLAN } \\ \mathrm{r} & : \text { Jari-jari AP } \\ \mathrm{P}_{\text {Transmit }} & : \text { Power transmit }\end{array}$

c. Selanjutnya menghitung jumlah access point berdasarkan kapasitas user dengan memperhatikan beberapa parameter pada Tabel 1. Menghitung user aktif dengan persamaan (7):

Kapasitas User : 2500

Estimasi User : 2500

$$
\begin{aligned}
\% \text { User } & =\frac{\sum \text { User }}{\text { User Maks }} \\
\% \text { User } & =\frac{2500}{2500}=1 \%
\end{aligned}
$$

- Bandwitdh per user dihitung dengan perasamaan (8):

$$
\begin{gathered}
B w-U \text { ser }=\frac{\frac{\text { Datarate }}{2}}{\text { User Maks }} \\
B w-U \text { ser }=\frac{\frac{100000}{2}}{2500}=\frac{50000}{2500}=20 \mathrm{Kbps}=0.02 \mathrm{Mbps}
\end{gathered}
$$

- Terakhir menentukan jumlah access point yang diperlukan dengan persamaan (9):

$$
\begin{aligned}
& N A P=\frac{0.02 \times 2500 \times 1}{1 \times 5} \\
& N A P=\frac{50}{5} 10 \mathrm{AP}
\end{aligned}
$$

- Perbedaan perhitungan jumlah AP dari kapasitas user dan coverage area ditampilkan seperti pada tabel 2 berikut:

Tabel 2. Hasil perhitungan jumlah access point berdasarkan kapasitas user dan coverage area

\begin{tabular}{c|c|c}
\hline Kapasitas User & Coverage Area & Simulasi \\
\hline 10 & 6 & 10 \\
\hline
\end{tabular}

d. Menentukan titik koordinat berdsarkan layout ruanganTransmiter ke-1 dengan posisi AP sebenarnya yang berada pada $(37,32)$, titik Transmitter kedua berada pada $(17,32)$, dan titik ketiga $(37,13)$. 
e. Terdapat 40 titik NLoS yang disebar secara acak di beberapa lantai pada 1 Gedung Auditorium Undiksha.

f. Mengukur besarnya nilai RSSI $\left(P_{\min }\right)$ dari sesuai bertambahnya jarak antara koordinat kedua Transmiter dan koordinat Receiver. Nilai yang diambil adalah nilai minimum dari RSSI menggunakan persamaan 10:

$$
\text { New RSSI }_{(i)}=\frac{T h_{(i)}}{\text { First Range }_{(i)}} \text { New Distance }
$$

Dimana $T h_{(i)}$ adalah Threshold $=-30 \mathrm{dBm}$, First Range ${ }_{(i)}=$ Range $_{(i)}$, sebelumnya ditentukan dengan menggunakan persamaan (11).

$$
\text { Range }_{(i)}=\frac{T h_{(i)} x \operatorname{Smax}}{P \min }[13]
$$

g. Sesuai dengan hasil penelitian, diperoleh data sebagai berikut:

- Pada koordinat access point $(37,32)$ dengan Hotspot UNDIKSHA-AUDIT-SELATAN1 menggunakan propagasi NLoS diperoleh data seperti pada tabel berikut:

Tabel 3. Contoh data variabel penentuan range propagasi NLoS

\begin{tabular}{l|l}
\hline Th & $:-30 \mathrm{dBm}$ \\
Smax & $: 34,2 \mathrm{~m}$ \\
Tinggi AP & $: 4$ Meter \\
RSSI & $:-50 \mathrm{dBm}$ \\
Skala Ruang & $: 100 \mathrm{~cm}$ \\
\hline
\end{tabular}

Untuk menentukan Range pada propagasi NLoS dengan tinggi AP adalah 4 m, maka diketahui:

$$
\begin{aligned}
s & =\frac{-30 \times 34,2}{-90} * 100=2052,3 \\
\text { Range } & =\frac{s^{-90}}{100}=\frac{2052,3}{100}=20,5 \text { Satuan Pixel }
\end{aligned}
$$

- Selanjutnya menghitung area tercover dari access point ketika nilai jarak kurang dari range yang telah ditentukan dengan menggunakan persamaan 12

$$
\sum_{\sigma 2=1}^{n} \sum_{\psi 2=1}^{n} \sqrt{\sqrt{ }(\sigma 1-\sigma 2) 2+(\psi 1-\psi 2) 2} \leq \rho
$$

- Berikut data yang didapat sesuai perhitungan pada point $\mathbf{h}$ diperoleh data pada tabel 4 berikut:

Tabel 4. Hasil perhitungan dari 3 AP

\begin{tabular}{c|c|c|c}
\hline Koordinat & 37,32 & 17,32 & 37,13 \\
Threshold & \multicolumn{3}{|c}{$-30 \mathrm{dBm}$} \\
Smax & $34,2 \mathrm{~m}$ & $29,4 \mathrm{~m}$ & $31,9 \mathrm{~m}$ \\
RSSI & $-50 \mathrm{dBm}$ & $-52 \mathrm{dBm}$ & $-50 \mathrm{dBm}$ \\
Skala Ruang & 100 & 100 & 100 \\
Range & 20.5 & 17.0 & 19.1 \\
CA & 307,3 & 215,0 & 234,4 \\
\hline
\end{tabular}

- Menghitung area tercover irisan (intersection) antara ketiga access point dengan rumus pada persamaan (13). Maka diperoleh area tercover irisan ketiga AP sebesar 538,5 skala koordinat.

$$
\begin{gathered}
A P 1 \cap A P 2 \cap A P 3=\sum_{x 2=1}^{n}, \sum_{y 2=1}^{n} \sqrt{(A P 1 \sigma 1-\sigma 2)^{2}+(A P 1 \psi 1-\psi 2)^{2}} \leq \\
\text { Range } \sum_{x 2=1}^{n}, \sum_{y 2=1}^{n} \sqrt{(A P 2 \sigma 1-\sigma 2)^{2}+(A P 2 \psi 1-\psi 2)^{2}} \leq \\
\text { Range } \sum_{x 2=1}^{n}, \sum_{y 2=1}^{n} \sqrt{(A P 3 \sigma 1-\sigma 2)^{2}+(A P 3 \psi 1-\psi 2)^{2}}<\text { Range }
\end{gathered}
$$

- Wilayah Coverage Area (\%) diperoleh dari persamaan (14) adalah luas dari area yang diamati $P$ x L [14]. Jadi, didapat persentase coverage area adalah sebesar:

$$
\zeta=\frac{\kappa \mathrm{AP} 1+\kappa \mathrm{AP} 2+\kappa \mathrm{AP} 3-\text { Intersection }}{\chi} \times 100 \%
$$




$$
\zeta=\frac{307,3+215+234,4-538,5}{2021} \times 100 \%
$$

2. Pemodelan Sistem berdasarkan Algoritma Simulated Anealing

Pada pemodelan ini menggunakan Simulated Annealing, akan dikembangkan sebuah model implementasi algoritma simulated annealing untuk penempatan posisi access point. Ketinggian AP yang digunakan adalah 4meter dari permukaan lantai di Auditorium Undiksha sebagai berikut:

a. Fungsi Objektif

Bertujuan untuk menemukan nilai dari daerah yang tertutup terbesar berdasarkan nilai dari jarak antara transmitter dan posisi receiver di antara sejumlah titik akses yang telah diinisialisasi secara acak.

b. Inisialisasi dan Mekanisme Pembentukan Solusi Baru.

Solusi awal untuk pembentukan penempatan titik akses diinisialisasi secara acak dengan cara membagi jalur akses secara acak ke dalam koordinat. Access point akan memancarkan nilai RSSI baru dari penerima pada titik koordinat tertentu yang telah ditentukan untuk menghasilkan perubahan jarak antara titik akses dan penerima.

c. Jadwal Pendinginan

Sebelum proses annealing dilakukan, jadwal pendingin harus ditetapkan terlebih dahulu. Setelah melakukan serangkaian percobaan pada berbagai kombinasi nilai parameter Annealing, dengan mempertimbangkan kualitas solusi dan komputasi waktu yang diperlukan, itu ditentukan dimana pendinginan jadwal $\mathrm{T}_{\text {awal }}=10, \mathrm{~T}_{\text {akhir }}=1, \alpha=0,8[15]$.

d. Proses Iterai

Proses iterasi merupakan kondisi dimana bertujuan untuk mencari nilai Coverage Area (\%) paling optimal untuk daerah yang tertutup di mana proses iterasi dilakukan tanpa nilai target maka solusi saat ini selalu dibandingkan dengan nilai sebelumnya untuk menunjukkan keakuratan nilai dari solusi.

Setelah dilakukannya uji coba optimisasi menggunakan metode SA dengan membangkitkan secara acak koordinat access point (random) dan jumlah AP yang diperlukan sesuai dengan kapasitas user dan coverage area yang menghasilkan 10 titik koordinat dari 3 access point yang berbeda ditampilkan dalam bentuk gambar seperti pada gambar (3), (4), dan (5) dan tabel (5), (6), dan (7):

Tabel 5. Hasil Program SA untuk AP1 dengan titik koordinat $(37,32)$

\begin{tabular}{c|c|c|c|c}
\hline \multicolumn{5}{c}{ Metode SA } \\
\hline $\begin{array}{c}\text { Titik } \\
\text { Koordinat }\end{array}$ & RSSI & CA & CA (\%) \\
\hline 1 & 23 & -50.0 & 406 & $20.1 \%$ \\
1 & 22 & -50.0 & 405 & $20.0 \%$ \\
8 & 2 & -49.9 & 405 & $20.0 \%$ \\
1 & 35 & -50.0 & 403 & $19.9 \%$ \\
1 & 32 & -49.9 & 400 & $19.8 \%$ \\
3 & 35 & -49.9 & 399 & $19.7 \%$ \\
6 & 4 & -50.1 & 396 & $19.6 \%$ \\
5 & 3 & -49.8 & 396 & $19.6 \%$ \\
9 & 2 & -49.8 & 395 & $19.5 \%$ \\
10 & 3 & -49.9 & 394 & $19.5 \%$ \\
\hline
\end{tabular}




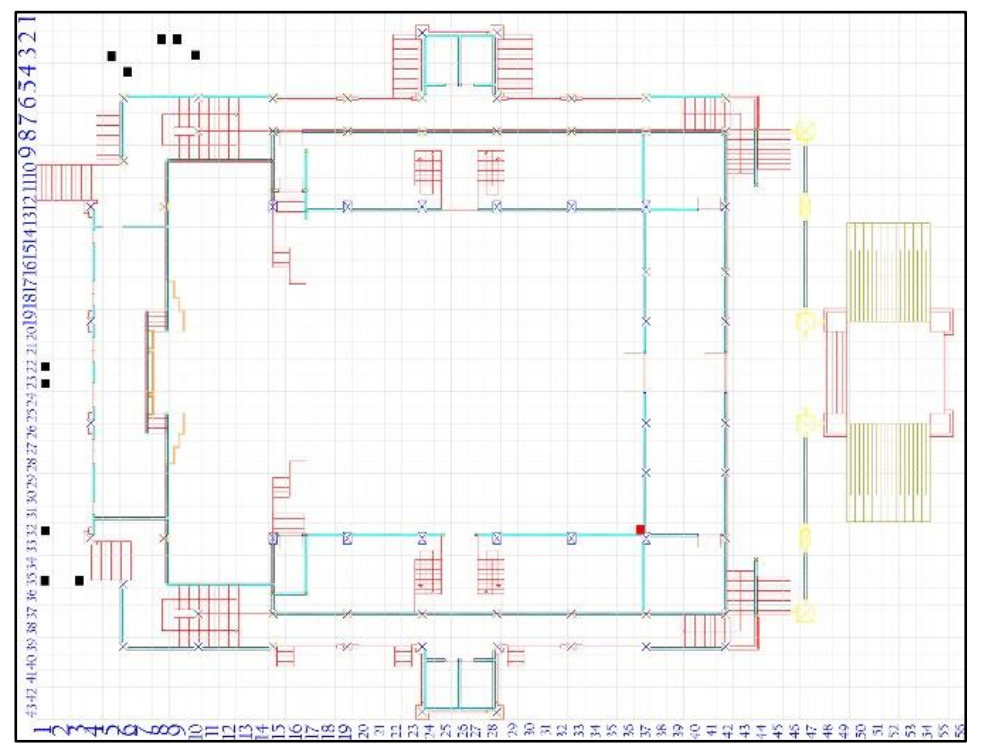

Gambar 3. Hasil pemodelan letak AP1 Eksisting (Merah) dengan algoritma Simulated Annealing (Hijau)

Tabel 6. Hasil Program SA untuk AP2 dengan titik koordinat $(17,32)$

\begin{tabular}{|c|c|c|c|c|}
\hline \multicolumn{5}{|c|}{ Metode SA } \\
\hline \multicolumn{2}{|c|}{$\begin{array}{c}\text { Titik } \\
\text { Koordinat }\end{array}$} & RSSI & CA & CA (\%) \\
\hline 1 & 32 & -50.0 & 374 & $18.5 \%$ \\
\hline 2 & 33 & -50.0 & 367 & $18.2 \%$ \\
\hline 1 & 27 & -49.9 & 367 & $18.2 \%$ \\
\hline 1 & 31 & -50.0 & 366 & $18.1 \%$ \\
\hline 3 & 24 & -49.9 & 366 & $18.1 \%$ \\
\hline 3 & 23 & -49.9 & 365 & $18.1 \%$ \\
\hline 2 & 24 & -50.1 & 363 & $18.0 \%$ \\
\hline 2 & 23 & -49.8 & 362 & $17.9 \%$ \\
\hline 1 & 30 & -49.8 & 359 & $17.8 \%$ \\
\hline 1 & 24 & -49.9 & 359 & $17.8 \%$ \\
\hline
\end{tabular}

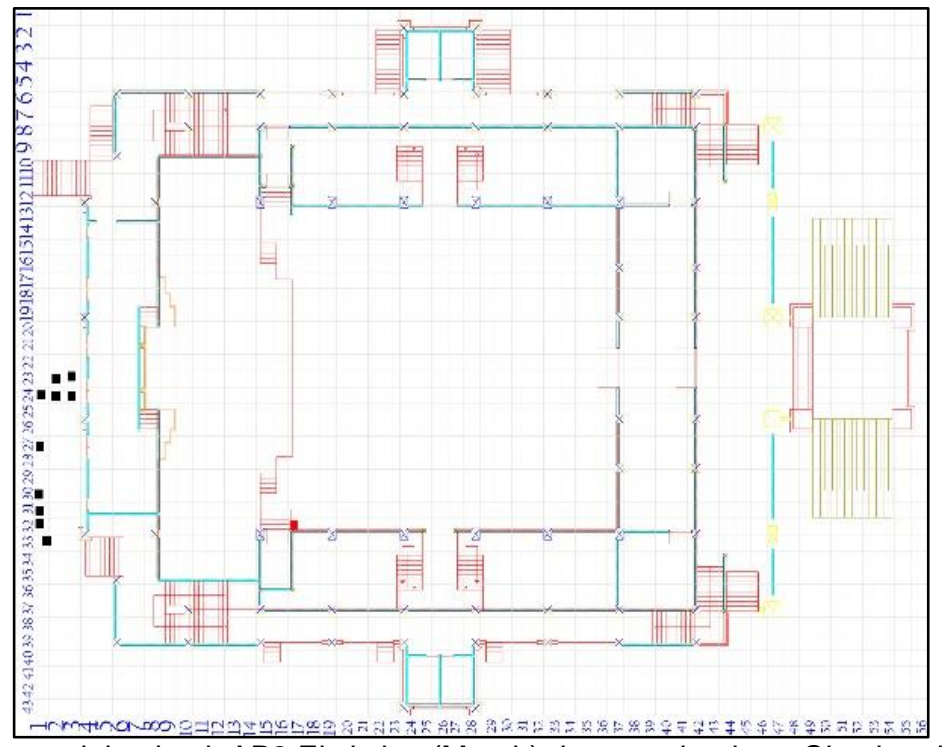

Gambar 4. Hasil pemodelan letak AP2 Eksisting (Merah) dengan algoritma Simulated Annealing (Hijau) 
Tabel 7. Hasil Program SA untuk AP3 dengan titik koordinat $(37,13)$

\begin{tabular}{c|c|c|c|c}
\hline \multicolumn{5}{c|}{ Metode SA } \\
$\begin{array}{c}\text { Titik } \\
\text { Koordinat }\end{array}$ & RSSI & CA & CA (\%) \\
\hline 6 & 3 & -50.0 & 411 & $20.3 \%$ \\
10 & 2 & -49.8 & 411 & $20.3 \%$ \\
1 & 33 & -49.8 & 410 & $20.3 \%$ \\
2 & 24 & -49.8 & 407 & $20.1 \%$ \\
4 & 3 & -50.0 & 407 & $20.1 \%$ \\
1 & 23 & -50.0 & 406 & $20.1 \%$ \\
8 & 2 & -50.0 & 405 & $20.0 \%$ \\
11 & 2 & -49.8 & 401 & $19.8 \%$ \\
3 & 35 & -49.8 & 399 & $19.7 \%$ \\
5 & 3 & -50.0 & 396 & $19.6 \%$ \\
\hline
\end{tabular}

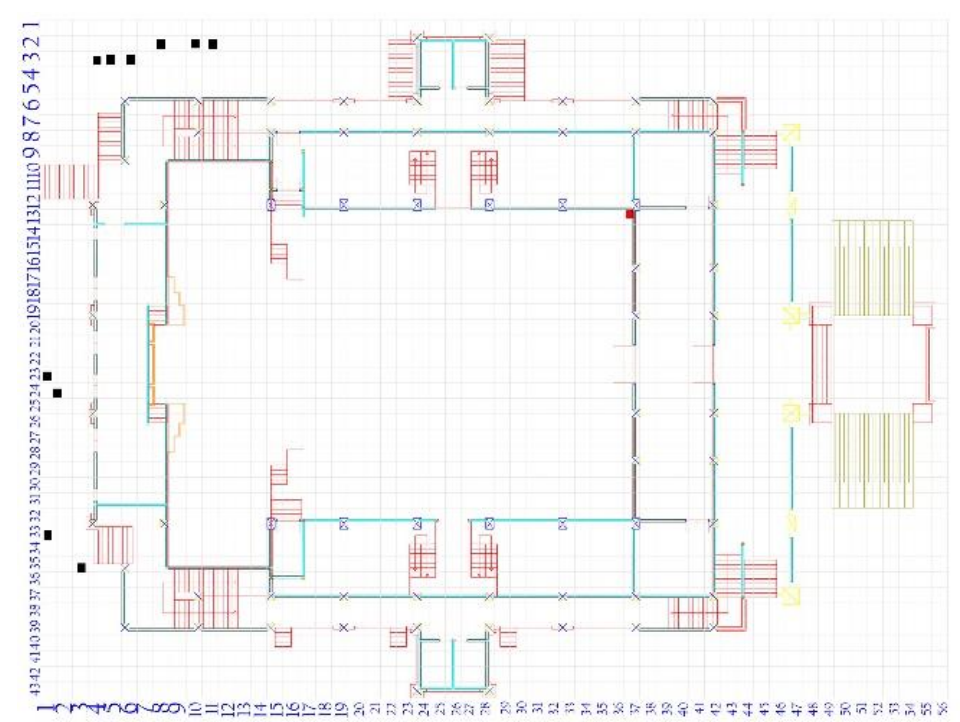

Gambar 5. Hasil pemodelan letak AP3 Eksisting (Merah) dengan algoritma Simulated Annealing (Hijau)

Berdasarkan pemaparan optimasi dengan algoritma Simulated Annealing dengan kondisi awal (Eksisting) terdapat adanya peningkatan coverage area yang ditampilkan ditampilkan dalam bentuk grafik seperti pada gambar 6 berikut:

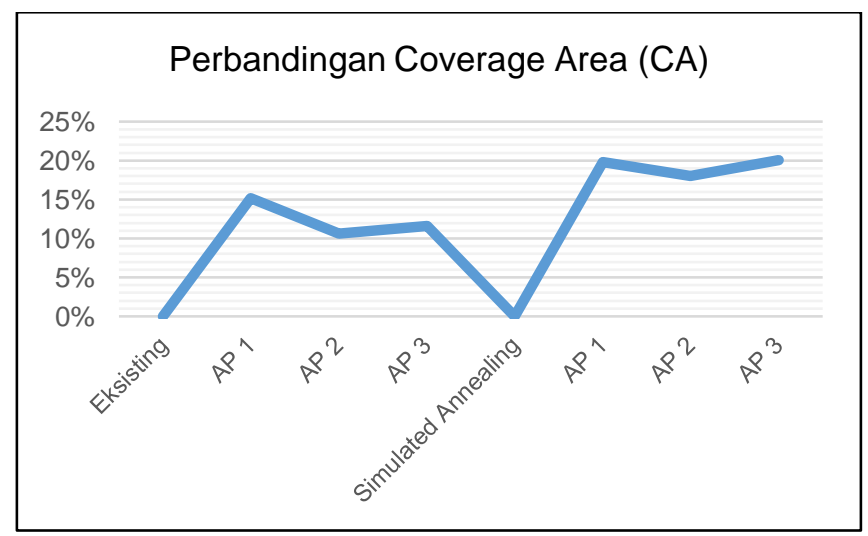

Gambar 6. Grafik perbandingan kondisi Eksisting dengan algoritma Simulated Annealing

Grafik diatas kondisi sebenarnya memiliki nilai Coverage Area (CA) sebesar 15\% untuk AP1 dengan titik koordinat $(37,32)$, untuk AP2 memperoleh nilai CA sebesar $11 \%$ dengan titik koordinat $(17,32)$, dan untuk AP3 memperoleh nilai CA sebesar $12 \%$ dengan titik koordinat $(37,13)$ serta area irisan sebesar 
538.5 skala koordinat sehingga persentase coverage area sebesar menjadi $11 \%$. Algoritma simulated annealing dengan menghasilkan 10 titik koordinat serta nilai CA yang lebih baik daripada pemodelan berdasarkan kondisi sebenarnya seperti gambar diatas dari 3 AP yang berbeda seperti pada tabel 8 berikut:

Tabel 8. Hasil Program SA dengan 10 titik koordinat Optimal

\begin{tabular}{c|c|c|c|c|c|c|c|c|}
\hline \multicolumn{3}{c|}{\begin{tabular}{c} 
AP1 \\
\multicolumn{2}{c|}{$(37,32)$}
\end{tabular}} & \multicolumn{3}{c|}{$\begin{array}{c}\text { AP2 } \\
(17,32)\end{array}$} & \multicolumn{3}{c}{$\begin{array}{c}\text { AP3 } \\
(37,13)\end{array}$} \\
\hline $\mathrm{x}$ & $\mathrm{y}$ & $\mathrm{CA} \%$ & $\mathrm{x}$ & $\mathrm{Y}$ & $\mathrm{CA} \%$ & $\mathrm{x}$ & $\mathrm{y}$ & $\mathrm{CA} \%$ \\
\hline 1 & 23 & $20.1 \%$ & 1 & 32 & $18.5 \%$ & 6 & 3 & $20.3 \%$ \\
1 & 22 & $20.0 \%$ & 2 & 33 & $18.2 \%$ & 10 & 2 & $20.3 \%$ \\
8 & 2 & $20.0 \%$ & 1 & 27 & $18.2 \%$ & 1 & 33 & $20.3 \%$ \\
1 & 35 & $19.9 \%$ & 1 & 31 & $18.1 \%$ & 2 & 24 & $20.1 \%$ \\
1 & 32 & $19.8 \%$ & 3 & 24 & $18.1 \%$ & 4 & 3 & $20.1 \%$ \\
3 & 35 & $19.7 \%$ & 3 & 23 & $18.1 \%$ & 1 & 23 & $20.1 \%$ \\
6 & 4 & $19.6 \%$ & 2 & 24 & $18.0 \%$ & 8 & 2 & $20.0 \%$ \\
5 & 3 & $19.6 \%$ & 2 & 23 & $17.9 \%$ & 11 & 2 & $19.8 \%$ \\
9 & 2 & $19.5 \%$ & 1 & 30 & $17.8 \%$ & 3 & 35 & $19.7 \%$ \\
10 & 3 & $19.5 \%$ & 1 & 24 & $17.8 \%$ & 5 & 3 & $19.6 \%$ \\
\hline
\end{tabular}

Penerapan algoritma Simulated Annealing di Gedung Auditorium mengalami beberapa kendala yaitu dalam menentukan ketinggian AP yang hanya sekali dalam perhitungan, selain itu sistem yang tidak bersifat multipoint karena dalam perhitungan pada sistem dilakukan 1 kondisi AP eksisting dimana hasilnya masih menumpuk dan diluar tembok karena pada sistem tidak diinputkan niali redaman dan penambahan fitur database guna menyimpan hasil perhitungan pada tiap iterasi.

\section{SIMPULAN DAN SARAN}

Berdasarkan pembahasan diatas terdapat beberapa kesimpulan, sebagai berikut:

Pada ukuran ketinggian AP $400 \mathrm{~cm}$ dengan propagasi NLoS, diperoleh persentase area sebesar $15 \%$ yaitu pada titik koordinat $(37,32)$ untuk access point pertama, persentase area sebesar $11 \%$ dengan titik koordinat $(17,32)$ untuk access point kedua, dan persentase area sebesar $12 \%$ dengan titik koordinat $(37,13)$ untuk access point ketiga, total coverage area dengan 3 AP sebesar $38 \%$ dengan area irisan tercover sebesar 538.5 skala koordinat sehingga persentase coverage area sebesar $11 \%$.

Hasil optimasi menggunakan algoritma simulated annealing dengan memperoleh 10 titik koordinat dari 3 AP yang berbeda diperoleh peningkatan rata-rata nilai coverage area dari ketiga access point yang dipilih diperoleh sebesar $20 \%$ untuk AP1, 18\% untuk AP2, dan 20\% untuk AP3.

Berdasarkan penelitian yang dilakukan ada beberapa saran yang nantinya bisa menunjang untuk penelitian selanjutnya diharapkan mampu menambahkan fungsi ke dalam sistem yang bisa menentukan ketinggian access point dengan nilai daya pancar sinyal dan bisa membangun sistem pemodelan Simulated Annealing yang besifat multipoint dan juga dapat menambahkan fitur database serta menambahkan parameter nilai redaman pada bahasa pemrograman Python sesuai dengan sistem yang dikembangkan guna menghasilkan coverage area yang lebih optimal.

\section{DAFTAR PUSTAKA}

[1] Ketut Agustini, Gede. Saindra Santyadiputra. Subak Analogy Model In Computer Network. Advances In Social Science, Education And Humanities Research (ASSEHR), Volume 201, 1-6. 2018.

[2] Afdhal, E. IEEE 802.11ac Sebagai Standar Pertama Untuk Gigabit Wireless Lan. Jurnal Rekayasa Elektrika, 36-44. 2014

[3] Prastise Titahningsih, R. P. Perancangan Penempatan Access Point Untuk Jaringan Wifi Pada Kereta Api Penumpang . Jurnal Pengembangan Teknologi Informasi Dan Ilmu Komputer, 20082015. 2018. 
[4] Nila Feby Puspitasari, H. A. Layout Optimization Of Wireless Access Point Placement Using Greedy And Simulated Annealing Algorithms. International Journal Of Simulation: Systems, Science And Technology, 14.1-14.12. 2016.

[5] Silmina Farhani Komalin, U. K. Analisa Perencanaan Indoor Wifi leee 802.11n Pada Gedung Tokong Nanas (Telkom University Lecture Center). Seminar Nasional Inovasi Dan Aplikasi Teknologi Di Industri (Seniati), 356-361. 2016.

[6] Sandy, F. N., Syafei, W. A., \& Santoso, I. Optimasi Ketinggian Access Point Pada Jaringan Wireless Distribution System. Transient, 5(Wireless Distribution System), 1-5. 2015.

[7] Anjar Wanto, J. T. Analisis Dan Pemodelan Posisi Access Point Pada Jaringan Wi-Fi Menggunakan Metode Simulate Annealing. Jurnal Sains Komputer \& Informatika (J-Sakti), 134143. 2017.

[8] Moh. Husni Taufik, M. F. Analisis Sinyal Wireless Berdasarkan Jarak Antar Access Point Menggunakan Metode Simulated Annealing Pada Sman 1 Praya Tengah. Jire (Jurnal Informatika \& Rekayasa Elektronika), 33-37. 2018.

[9] Suyanto. Algoritma Optimasi Deterministik Atau Probabilistik. Yogyakarta: Graha IImu. 2010.

[10] Chibante, R. (2010). Simulated Annealing. Rijeka, Croatia: Sciyo.

[11] Rummi, S. Optimasi Penempatan Access Point Pada Jaringan Wi-Fi Di Universitas Budi Luhur. Arsitron, 1-7. 2017.

[12] Siswanto, A. Evaluasi Kinerja Wireless 802.11 n Untuk E- Learning. It Journal Research And Development, 1-13. 2017.

[13] Sari, P. I., Tribudi, S., \& Siswandi, A. N. Optimasi Penataan Sistem Wi-Fi di PENS-ITS dengan Menggunakan Metode Monte Carlo. (July), 1-7. 2010.

[14] Siregar, M. R., \& Sari, L. O. Optimasi Wireless Access Point Menggunakan Algoritma Genetika ( Studi Kasus Gedung C Fakultas Teknik ). 5, 1-8. 2018.

[15] Samana, E., Prihandono, B., \& Noviani, E. Aplikasi Simulated Annealing Untuk Menyelesaikan Travelling Salesman Problem. Buletin IImiah Mat. Stat. Dan Terapannya, 03(1), 25-32. 2015. 